\title{
AMINO ACIDS CONTENT IN TRITICALE GRAIN DEPENDING ON METEOROLOGICAL, AGROTECHNICAL AND GENETIC FACTORS
}

\author{
Boguslawa Jaśkiewicz ${ }^{1}$, Malgorzata Szczepanek ${ }^{2}$ \\ ${ }^{1}$ Institute of Soil Science and Plant Cultivation - State Research Institute, Poland \\ ${ }^{2}$ University of Science and Technology, Poland \\ kos@iung.pulawy.pl
}

\begin{abstract}
The field studies were conducted in the years of 2011 and 2014 at the Experimental Station in Osiny, Poland. Triticale (Triticosecale) is a valuable fodder cereal with a high nutritional value of grains. It can also gain importance as a consumer cereal, providing the body with the necessary amino acids. The aim of the study was to determine the influence of precipitation and temperature conditions in the harvest year, agronomic factors (intensive or integrated type of production) and the percentage of cereals in crop rotation $(50,75$ and $100 \%)$ on the amino acid content of two winter triticale cultivars ('Pizarro' and 'Pigmej') as well as to determine the nutritive value of the protein: chemical score (CS) and essential amino acid index (EAAI). Our studies have shown that although the amino acid content of winter triticale is strongly genetically determined, it also depends on weather and agrotechnical factors. Precipitation and temperature factors had the biggest effect on the tyrosine (Tyr) content. The contents of essential and non-essential amino acids in triticale grains and EAAI value were higher under intensive technology, with $50 \%$ of cereal grains in the crop rotation, and in the traditional cultivar 'Pizarro' as compared to the dwarf one 'Pigmej'. The most important amino acids that limit the quality of protein in the grain are lysine (Lys) and tryptophan (Trp). Using intensive technology, reducing the cereal percentage of cereals in the crop rotation and selecting a proper cultivar, it is possible to maximize the content of the desired essential and non-essential amino acids in the triticale grains, and thereby improve their feed and consumer value.
\end{abstract}

Key words: crop rotation, cultivar, intensity of technology.

\section{Introduction}

Triticale (Triticosecale) is one of the most widely distributed cereals in Europe and Asia. According to FAOSTAT (2016), in 2014 this species was cultivated in 37 countries on the area of 4.1 million ha, its production amounting to 17.1 million tons. Major triticale producers include Poland, Germany, Belarus, France and Russia. Triticale grains are mainly used as valuable feed for animals, but they are becoming more and more popular as consumer grain (Coffey \& Gerrits, 2009). Triticale has a high nutritional value due to its high content of protein in grains and a better amino acid composition than wheat (Alijošius et al., 2016). The quality of cereal grain is shaped by the complex activity of habitat, agronomic and genetic factors (Djekić et al., 2014; Järvan et al., 2017). It is therefore advisable to find out the response of triticale to these factors in terms of the content of individual amino acids. One of the most important aspects of such an analysis should be the concentration of essential amino acids that are not synthesized, or synthesized in unsatisfying quantities, by human and animal organisms. Few studies on triticale indicate the differentiation of amino acid content in grains under the influence of agronomic factors such as terminal water stress (Fernandez-Figares et al., 2000), sowing density, herbicides (Stankiewicz, 2005), and fertilization (Brzozowska, Brzozowski, \& Hruszka, 2009). The aim of our study was to evaluate the impact of cereal percentage in the crop rotation (50, 75 and $100 \%$ ), technology of cultivation (integrated, intensive) and a cultivar (dwarf and traditional) on the amino acid concentration in the grains of winter triticale in different growing seasons, varying precipitation and temperature condition.

\section{Materials and Methods}

The studies were conducted in the years of 2011 and 2014 at the Experimental Station in Osiny $\left(51^{\circ} 27^{\prime}\right.$ $\mathrm{N} ; 22^{\circ} 2^{\prime} \mathrm{E}$ ), Poland. The experiment was located on a lessive soil (Luvisol), on plots with the area of $45 \mathrm{~m}^{2}$, in 4 replicates. The soil had a slightly acidic $\mathrm{pH}(\mathrm{pH}$ KCL 6.5) and contained $1.73 \mathrm{mg}$ of P, $1.81 \mathrm{mg}$ of K and $1.08 \mathrm{C}_{\mathrm{org}} \mathrm{gkg}^{-1}$. Each year, an experiment was set up on the existing long-term field experiments with a 100\% (spring barley (Hordeum L.), winter wheat (Triticum aestivum L.), winter triticale (Triticosecale)), 75\% (spring barley, winter rapeseed (Brassica napus L.), winter wheat, winter triticale) and a $50 \%$ share of cereals in crop rotation (winter rapeseed, winter wheat, faba bean (Vicia faba L.), winter triticale). Two technologies - integrated and intensive - were investigated within each crop rotation. They differed in terms of the rates of mineral fertilizers and the intensity of chemical plant protection (Table 1).

Two Polish winter triticale cultivars: 'Pizarro' and 'Pigmej' were studied. The dwarf cultivar 'Pigmej' forms a straw of the length of $95 \mathrm{~cm}$. The traditional cultivar 'Pizarro' has a longer straw $(115 \mathrm{~cm})$ and, moreover, it is more resistant to powdery mildew (Blumeria graminis) and septoriosis (Septoria tritici) (Variety Descriptive List, 2017).

Sowing was carried out September 26 - 29 with the Amazone drill. The sowing density of triticale was 
Characterization of applied technologies for triticale production

\begin{tabular}{|c|c|c|}
\hline \multirow{2}{*}{ Specification } & \multicolumn{2}{|r|}{ Technologies } \\
\hline & Integrated & Intensive \\
\hline \multicolumn{3}{|c|}{ Fertilization $\left(\mathrm{kg} \mathrm{ha}^{-1}\right)$} \\
\hline $\mathrm{N}$ (ammonium nitrate) & $\begin{array}{l}50 \text { (stage of spring tillering) } \\
50(\mathrm{BBCH} 31)\end{array}$ & $\begin{array}{l}60 \text { (stage of spring tillering) } \\
60 \text { (BBCH 31) } \\
30(\mathrm{BBCH} 51) \\
\end{array}$ \\
\hline $\mathrm{P}$ (superfhosphate) & $29 \mathrm{P}_{2} \mathrm{O}_{5}$ & $35 \mathrm{P}_{2} \mathrm{O}_{5}$ \\
\hline $\mathrm{K}$ (potassium salt) & $59 \mathrm{~K}_{2} \mathrm{O}$ & $76 \mathrm{~K}_{2} \mathrm{O}$ \\
\hline \multicolumn{3}{|c|}{ Pesticides } \\
\hline Herbicides & $\begin{array}{l}\text { BBCH 31: 2,4 D + dikamba }(3.0 \\
\left.1 \text { ha }^{-1}\right)\end{array}$ & $\begin{array}{l}\text { BBCH 25: diflufenican, iodosulfuron-metyl-sodium, } \\
\text { mesosulfuron- metyl }\left(0.81 \mathrm{ha}^{-1}\right) \\
\text { BBCH 31: } 2,4 \mathrm{D}+\operatorname{dicamba}\left(3.01 \mathrm{ha}^{-1}\right) \\
\text { BBCH 34: clopyralid }\left(0.41 \mathrm{ha}^{-1}\right)\end{array}$ \\
\hline Fungicides & $\begin{array}{l}\text { BBCH 45: difenokonazol + } \\
\text { paclobutrazol }\left(0.81 \mathrm{ha}^{-1}\right)\end{array}$ & $\begin{array}{l}\text { BBCH 31: flusilazol+carbendazim } \\
\text { BBCH 45: difenoconazole + paclobutrazol }\left(1.01 \mathrm{ha}^{-1}\right)\end{array}$ \\
\hline Insecticides & - & $\begin{array}{l}\text { BBCH 47: deltamethrin }+ \\
\text { dimethylcyclopropanecarboxylate }\left(0.41 \mathrm{ha}^{-1}\right)\end{array}$ \\
\hline Retardants & $\begin{array}{l}\text { BBCH 32: trinexapak etylu ( } 0.31 \\
\left.\text { ha }^{-1}\right)\end{array}$ & BBCH 32: trinexapak etylu $\left(0.31 \mathrm{ha}^{-1}\right)$ \\
\hline
\end{tabular}

$4 \mathrm{mln} \mathrm{ha}^{-1}$. Harvesting was carried out in the middle of August. Immediately after the harvesting, grain samples were collected. Amino acid content in winter triticale grains, with the exception of tryptophan (Trp), was detected by ultrasonic liquid chromatography with spectrophotometric detection (UPLC-UV) on Waters Acquity apparatus. Tryptophan was determined using high performance liquid chromatography with fluorescence detection (HPLC-FLD).

The nutritive value of the protein was determined on the basis of the chemical score and essential amino acid indices, taking the whole chicken egg protein as the standard protein. The chemical score (CS) of restrictive amino acid(s) was calculated by comparing the amount of individual essential amino acids contained in the test protein (ai) with their content in their standard protein (as): chemical score $=($ ai $/$ as $)$ $\times 100$ (FAO, 1985). The essential amino acid index (EAAI) was calculated as the geometric mean of all essential amino acids against the content of these amino acids in the standard. The obtained results were statistically worked out using the software Statistica, with the method of the analysis of variance ANOVA, and the differences were estimated with Tukey's test at $\alpha=0.05$. The relation of the amino acid content to the proteins in the grain and the thousand kernel weight was expressed by Pearson's correlation coefficients.

Weather conditions from the $\mathrm{BBCH} 31$ to $\mathrm{BBCH}$ 87 (May - July) during the study years were different (Table 2). In May and, especially in June 2011 the temperatures were higher and the rainfall in these months was more than half lower in comparison to

Weather conditions at the experimental site

\begin{tabular}{|c|c|c|c|c|c|c|}
\hline \multirow{3}{*}{ Month } & \multicolumn{6}{|c|}{ Year } \\
\hline & 2011 & 2014 & $1981-2010$ & 2011 & 2014 & $1981-2010$ \\
\hline & \multicolumn{3}{|c|}{ Temperature $\left({ }^{\circ} \mathrm{C}\right)$} & \multicolumn{3}{|c|}{ Precipitation $(\mathrm{mm})$} \\
\hline March & 3.0 & 6.7 & 1.6 & 11 & 31 & 30 \\
\hline April & 10.7 & 10.7 & 7.8 & 27 & 58 & 40 \\
\hline May & 14.6 & 14.3 & 13.5 & 60 & 172 & 57 \\
\hline June & 19.2 & 16.5 & 16.8 & 54 & 93 & 70 \\
\hline July & 18.7 & 20.9 & 18.5 & 250 & 68 & 84 \\
\hline Mean / sum & 13.2 & 13.8 & 11.6 & 402 & 422 & 281 \\
\hline
\end{tabular}


the year 2014. Particularly large rainfall-related differences in the years of research occurred in July (BBCH83-BBCH89). In 2011 this month was much cooler and the total precipitation was 3.7 times higher compared to 2014 .

\section{Results and Discussion}

The amino acid content in winter triticale was dependent on hydrothermal conditions during the study years, percentage of cereals in the crop rotation, cultivation technology, and the cultivar (Table 3). In 2011, the total of essential and non-essential acids in the grains were higher than in 2014 , by respectively
$8.6 \%$ and $10.7 \%$. It was promoted by the abundant rainfall during the $\mathrm{BBCH} 73$ - BBCH 89 (July 2011) (Table 2), which caused a significant increase in the content of almost all amino acids. Only in the case of Valine (Val), Proline (Pro) and Glysine (Gly), the differences between the years were not significant. The interaction analysis showed that Val and Pro showed no differences between the years of the study, only under intensive technology (data not shown). Among essential amino acids, the reduction in the amino acid content in 2014 was the biggest for Lysine (Lys) (by $12.7 \%$ ), while among non-essential ones, for Tyrosine (Tyr) (by 36.9\%). A similar relationship between the

Table 3

\section{The contents of essential amino acids in grains of winter triticale depending on harvest year, production technology and a cultivar $\left(\mathrm{g} \mathrm{kg}^{-1}\right)$}

\begin{tabular}{|c|c|c|c|c|c|c|c|c|c|c|}
\hline \multirow{2}{*}{$\begin{array}{l}\text { Amino } \\
\text { acid* }\end{array}$} & \multicolumn{2}{|c|}{$\begin{array}{l}\text { The year of } \\
\text { harvest }\end{array}$} & \multicolumn{3}{|c|}{$\begin{array}{l}\text { Percentage of cereals in the } \\
\text { crop rotation }(\%)\end{array}$} & \multicolumn{2}{|c|}{ Production technology } & \multicolumn{2}{|c|}{ Cultivars } & \multirow[t]{2}{*}{ Mean } \\
\hline & 2011 & 2014 & 50 & 75 & 100 & integrated & intensive & Pizarro & Pigmej & \\
\hline Thr & $3.84 a$ & $3.54 \mathrm{~b}$ & $3.88 \mathrm{a}$ & $3.68 \mathrm{~b}$ & $3.51 \mathrm{c}$ & $3.60 \mathrm{~b}$ & $3.78 \mathrm{a}$ & $3.81 \mathrm{a}$ & $3.56 \mathrm{~b}$ & 3.68 \\
\hline Val & $5.01 \mathrm{a}$ & $4.95 \mathrm{a}$ & $5.19 a$ & $5.01 \mathrm{~b}$ & $4.74 \mathrm{c}$ & $4.87 \mathrm{~b}$ & $5.09 \mathrm{a}$ & $5.10 \mathrm{a}$ & $4.85 \mathrm{~b}$ & 4.97 \\
\hline Ile & $4.07 \mathrm{a}$ & $3.63 b$ & $4.05 \mathrm{a}$ & $3.82 b$ & $3.69 \mathrm{c}$ & $3.74 b$ & $3.96 a$ & $3.91 \mathrm{a}$ & $3.78 b$ & 3.84 \\
\hline Leu & $7.69 a$ & $7.08 \mathrm{~b}$ & $7.75 \mathrm{a}$ & $7.34 b$ & $7.07 \mathrm{c}$ & $7.18 b$ & $7.59 \mathrm{a}$ & $7.61 \mathrm{a}$ & $7.26 \mathrm{~b}$ & 7.43 \\
\hline Phe & $5.47 \mathrm{a}$ & $5.07 \mathrm{~b}$ & $5.70 \mathrm{a}$ & $5.14 \mathrm{~b}$ & $4.99 \mathrm{c}$ & $5.03 \mathrm{~b}$ & $5.51 \mathrm{a}$ & $5.33 \mathrm{a}$ & $5.21 \mathrm{a}$ & 5.27 \\
\hline His & $2.83 a$ & $2.58 \mathrm{~b}$ & $2.87 \mathrm{a}$ & $2.67 \mathrm{~b}$ & $2.57 \mathrm{c}$ & $2.61 \mathrm{~b}$ & $2.80 \mathrm{a}$ & $2.75 \mathrm{a}$ & $2.65 \mathrm{a}$ & 2.70 \\
\hline Lys & $3.95 \mathrm{a}$ & $3.45 b$ & $3.75 \mathrm{a}$ & $3.77 \mathrm{a}$ & $3.59 \mathrm{~b}$ & $3.71 \mathrm{a}$ & $3.69 \mathrm{a}$ & $3.88 \mathrm{a}$ & $3.51 \mathrm{~b}$ & 3.69 \\
\hline Arg & $5.44 \mathrm{a}$ & $5.07 \mathrm{~b}$ & $5.59 \mathrm{a}$ & $5.21 \mathrm{~b}$ & $4.98 \mathrm{c}$ & $5.11 \mathrm{~b}$ & $5.41 \mathrm{a}$ & $5.48 \mathrm{a}$ & $5.13 b$ & 5.30 \\
\hline Met & $2.29 \mathrm{a}$ & $2.05 \mathrm{~b}$ & $2.29 \mathrm{a}$ & $2.19 \mathrm{ab}$ & $2.04 \mathrm{~b}$ & $2.13 \mathrm{a}$ & $2.21 \mathrm{a}$ & $2.31 \mathrm{a}$ & $2.13 b$ & 2.22 \\
\hline Trp & $1.13 \mathrm{a}$ & $1.05 \mathrm{~b}$ & $1.11 \mathrm{a}$ & $1.10 \mathrm{a}$ & $1.07 \mathrm{a}$ & $1.04 \mathrm{~b}$ & $1.15 \mathrm{a}$ & $1.12 \mathrm{a}$ & $1.07 \mathrm{a}$ & 1.09 \\
\hline Total & $41.82 \mathrm{a}$ & $38.51 \mathrm{~b}$ & $42.18 \mathrm{a}$ & $39.93 b$ & $38.02 \mathrm{c}$ & $39.02 b$ & $41.19 \mathrm{a}$ & $41.3 \mathrm{a}$ & $39.15 b$ & 40.19 \\
\hline
\end{tabular}

$\mathrm{a}, \mathrm{b}, \mathrm{c}-$ different letters denote statistically significant differences $(\alpha=0.05)$.

* - Thr (threonine), Val(valine), Ile(isoleusine), Leu(leusine), Phe(phenylalanine), His(histidine), Lys(lysine), Arg(arginine), Met(methionine), Trp(tryptophan), Ser(serine),Asp(asparanine), Glu(glutamine), Pro(proline), Gly(glysine), Ala(alanine), Tyr(tyrosine), Cys(cysteine).

Table 4

The contents of non-essential amino acids in grains of winter triticale depending on harvest year, production technology and a cultivar $\left(\mathrm{g} \mathrm{kg}^{-1}\right)$

\begin{tabular}{|c|c|c|c|c|c|c|c|c|c|c|}
\hline \multirow{2}{*}{$\begin{array}{c}\text { Amino } \\
\text { acid* }\end{array}$} & \multicolumn{2}{|c|}{$\begin{array}{c}\text { The year of } \\
\text { harvest }\end{array}$} & \multicolumn{2}{c|}{$\begin{array}{c}\text { Percentage of cereals in the } \\
\text { crop rotation (\%) }\end{array}$} & \multicolumn{2}{|c|}{ Production technology } & \multicolumn{3}{|c|}{ Cultivars } & \multirow{2}{*}{ Mean } \\
\cline { 2 - 13 } & 2011 & 2014 & 50 & 75 & 100 & integrated & intensive & Pizarro & Pigmej & \\
\hline Ser & $5.54 \mathrm{a}$ & $5.23 \mathrm{~b}$ & $5.68 \mathrm{a}$ & $5.37 \mathrm{~b}$ & $5.10 \mathrm{c}$ & $5.20 \mathrm{~b}$ & $5.56 \mathrm{a}$ & $5.47 \mathrm{a}$ & $5.29 \mathrm{~b}$ & 5.38 \\
\hline Asp & $8.10 \mathrm{a}$ & $6.74 \mathrm{~b}$ & $7.62 \mathrm{a}$ & $7.57 \mathrm{a}$ & $7.07 \mathrm{~b}$ & $7.42 \mathrm{a}$ & $7.42 \mathrm{a}$ & $7.67 \mathrm{a}$ & $7.17 \mathrm{~b}$ & 7.42 \\
\hline Glu & $31.65 \mathrm{a}$ & $28.44 \mathrm{~b}$ & $31.73 \mathrm{a}$ & $30.08 \mathrm{~b}$ & $28.33 \mathrm{c}$ & $29.17 \mathrm{~b}$ & $30.92 \mathrm{a}$ & $29.82 \mathrm{a}$ & $30.26 \mathrm{a}$ & 30.04 \\
\hline Pro & $10.86 \mathrm{a}$ & $10.23 \mathrm{a}$ & $11.30 \mathrm{a}$ & $10.55 \mathrm{~b}$ & $9.88 \mathrm{c}$ & $10.19 \mathrm{a}$ & $10.96 \mathrm{a}$ & $10.5 \mathrm{a}$ & $10.65 \mathrm{a}$ & 10.57 \\
\hline Gly & $4.75 \mathrm{a}$ & $4.69 \mathrm{a}$ & $4.98 \mathrm{a}$ & $4.70 \mathrm{~b}$ & $4.50 \mathrm{c}$ & $4.58 \mathrm{~b}$ & $4.86 \mathrm{a}$ & $4.90 \mathrm{a}$ & $4.55 \mathrm{~b}$ & 4.72 \\
\hline Ala & $4.89 \mathrm{a}$ & $4.30 \mathrm{~b}$ & $4.75 \mathrm{a}$ & $4.66 \mathrm{a}$ & $4.37 \mathrm{~b}$ & $4.55 \mathrm{a}$ & $4.64 \mathrm{a}$ & $4.78 \mathrm{a}$ & $4.40 \mathrm{~b}$ & 4.59 \\
\hline Tyr & $3.06 \mathrm{a}$ & $1.93 \mathrm{~b}$ & $2.71 \mathrm{a}$ & $2.41 \mathrm{~b}$ & $2.39 \mathrm{~b}$ & $2.48 \mathrm{a}$ & $2.51 \mathrm{a}$ & $2.58 \mathrm{a}$ & $2.42 \mathrm{~b}$ & 2.50 \\
\hline Cys & $2.25 \mathrm{a}$ & $1.89 \mathrm{~b}$ & $2.18 \mathrm{a}$ & $2.09 \mathrm{a}$ & $1.94 \mathrm{~b}$ & $2.04 \mathrm{a}$ & $2.11 \mathrm{a}$ & $2.16 \mathrm{a}$ & $1.99 \mathrm{~b}$ & 2.07 \\
\hline Total & $71.1 \mathrm{a}$ & $63.45 \mathrm{~b}$ & $70.95 \mathrm{a}$ & $67.43 \mathrm{~b}$ & $63.58 \mathrm{c}$ & $65.63 \mathrm{~b}$ & $68.98 \mathrm{a}$ & $67.88 \mathrm{a}$ & $66.73 \mathrm{~b}$ & 67.29 \\
\hline
\end{tabular}

$\mathrm{a}, \mathrm{b}, \mathrm{c}, *-$ see Table 3 
amino acid content and weather was also presented by Stankiewicz (2005), who in comparable precipitation conditions, found an increased concentration of essential amino acids (by $10.6-13.4 \%$ ) in spring triticale. However, in the studies of Brzozowska, Brzozowski \& Hruszka (2009), heavy rainfall in the maturing stage of winter triticale increased the content of only four amino acids: Lysine, Phenylalanine (Phe), Histidine (His) and Arginine (Arg). In the study involving 15 cultivars of winter wheat, weather conditions had the biggest impact on Lysine and Isoleusine (Ile) (Spychaj-Fabisiak et al., 2014).

Growing triticale in a crop rotation with lower cereal percentage is better for growth and development of this plant and its yields mainly due to a lower pest pressures. Also, it is more beneficial for the soil than using cereal monocultures which damage its physicochemical conditions (Gałązka et al., 2017). In our studies, under the reduced, down to $50 \%$, amount of cereals in the crop rotation, we recorded a higher amount of the sums of both essential and non-essential amino acids in the grain in comparison with a $75 \%$ share of cereals, while the concentration of the two groups of amino acids was the lowest in cereal monoculture (with a $100 \%$ cereal share) (Table 3, 4). However, the response of certain amino acids to cereal percentage in the crop rotation was weaker. The contents of Lys, Asp, Ala and Cys were similar under $50 \%$ and $75 \%$ shares of cereals; Tyr content was not significantly different at $75 \%$ and $100 \%$, while Trp content was similar at 50, 75 and $100 \%$ of cereal share in the rotation. The decrease in the percentage of cereals from $100 \%$ down to $50 \%$ caused an increase in the content of essential amino acids from $3.7 \%$ (Trp) to $14.2 \%$ (Phe), while of the non-essential ones, from $7.8 \%$ (Asp) to $14.4 \%$ (Pro).

Our previous work has shown that triticale grown under intensive technology that uses higher doses of NPK fertilizers and a bigger number of pesticide treatments (intensive technology), tends to have higher total protein content than triticale in the integrated technology (Jaśkiewicz \& Szczepanek, 2016). In this study, the analysis of amino acid content showed that the production technologies (intensive and integrated) differentiated the total content of essential and nonessential amino acids to the advantage of intensive technology (Table 3, 4). The highest increase in amino acid content under the intensive technology (with higher doses of NPK and pesticides) was noted for Trp $(10.6 \%)$. However, the reaction of some amino acids was different. In the case of essential amino acids, the technology applied did not affect the contents of Lys and Met, while among non-essential amino acids, no response was recorded in the case of Asp, Pro, Ala, Tyr and Cys. Interaction analysis showed that the difference in the contents of Met and Asp between the compared technologies was significant only in the case of cultivar 'Pigmej' (data not shown). Marczak et al. (2001), comparing the impact of $\mathrm{N}$ fertilization

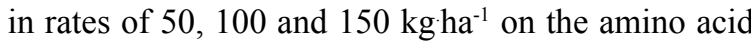
content in triticale, showed that the highest values of essential amino acids, with the exception of Lys, were obtained under $100 \mathrm{~kg} \mathrm{~N} \mathrm{~kg} \cdot \mathrm{ha}^{-1}$. In the studies of Brzozowska, Brzozowski \& Hruszka (2009), differences in the rate and division of the dose of mineral nitrogen differentiated the content of amino acids in the proteins only in the case of Met, Val and Glu. Few studies on the effect of chemical protection on the content of individual amino acids in triticale grains show no significant differences after herbicide application compared to control (without using the product) (Brzozowska, Brzozowski, \&Hruszka, 2009).

In our studies, the sum of essential and nonessential amino acids in winter triticale cultivar 'Pizarro' was significantly higher than in cultivar 'Pigmej'. However, the content of amino acids such as Phe, His, Trp, Glu and Pro in the grains was similar in both cultivars. In turn, Fernandez-Figares et al. (2000) showed varietal differences in the concentration of amino acids in triticale only for two amino acids: Lys and Met. Alijošius et al. (2016), in their studies involving 7 winter triticale genotypes showed variation in the concentration of all 16 amino acids tested, with the difference being the highest for Met, followed by Phe, Glu and Pro.

In our study, we found a negative correlation between the total content of essential amino acids and the thousand kernel weight, but in the case of nonessential amino acids, no such relationship occurred (Table 5).

The total protein content in the grains was positively correlated to the content of almost all essential (except for Lys) and non-essential (except for Asp and Cys) amino acids (Table 5). Fernandez-Figares et al. (2000) reported that the percentage of amino acids in the grain increased linearly with grain-protein content, but this relationship was not non-linear in the same degree for all amino acids. According to Biel \& Jacyno (2013), the coefficients of nutritive value of barley grain protein does not improve with an increased level of protein, which is most often due to increases in the lysine-poor prolamines.

The relationship of amino acid content and grain yield was small (Table 5). Only the content of two amino acids (Tyr and Cys) was negatively correlated with the yield. The greatest variation coefficient was found for the content of Tyr, while the lowest, for Val.

It is commonly known that cereals have a low Lys content (Stankiewicz, 2005; Shewry, 2007). Similarly, in our studies, based on the value of the limiting amino acid (CS), we found that Lys was the most 
The relationship between the contents of amino acids, the grain yield of winter triticale, a thousand kernel weight and the total protein content in the grains (Pearson's simple correlation coefficient) and variation coefficient

\begin{tabular}{|c|c|c|c|c|}
\hline $\begin{array}{l}\text { Amino } \\
\text { acid }\end{array}$ & $\begin{array}{l}\text { Grain } \\
\text { yield }\end{array}$ & $\begin{array}{c}\text { Thousand } \\
\text { kernel weight }\end{array}$ & $\begin{array}{l}\text { Total protein } \\
\text { content }\end{array}$ & $\begin{array}{c}\text { Variation } \\
\text { coefficient } \\
V(\%)\end{array}$ \\
\hline \multicolumn{5}{|c|}{ Essential amino acids } \\
\hline Thr & -0.29 & -0.09 & $0.58 *$ & 10.0 \\
\hline Val & -0.25 & -0.12 & $0.51 *$ & 8.9 \\
\hline Ile & -0.18 & -0.16 & $0.48 *$ & 11.1 \\
\hline Leu & -0.13 & -0.15 & $0.51 *$ & 9.8 \\
\hline Phe & -0.05 & 0.05 & $0.67 *$ & 11.7 \\
\hline His & -0.08 & 0.05 & $0.69 *$ & 10.2 \\
\hline Lys & -0.38 & -0.16 & 0.20 & 11.7 \\
\hline Arg & -0.28 & 0.06 & $0.64 *$ & 10.3 \\
\hline Met & -0.22 & -0.17 & $0.41 *$ & 10.5 \\
\hline $\operatorname{Trp}$ & -0.09 & -0.12 & $0.42 *$ & 10.6 \\
\hline Total & 0.39 & $-0.42 *$ & $0.57 *$ & - \\
\hline \multicolumn{5}{|c|}{ Non-essential amino acids } \\
\hline Ser & -0.09 & -0.08 & $0.61 *$ & 9.7 \\
\hline Asp & -0.32 & -0.09 & 0.37 & 12.9 \\
\hline Glu & 0.10 & -0.18 & $0.43 *$ & 11.9 \\
\hline Pro & 0.12 & -0.09 & $0.53 *$ & 11.3 \\
\hline Gly & -0.25 & -0.04 & $0.63 *$ & 9.2 \\
\hline Ala & -0.37 & -0.18 & $0.40 *$ & 11.2 \\
\hline Tyr & $-0.68^{*}$ & 0.03 & $0.40 *$ & 26.1 \\
\hline Cys & $-0.43^{*}$ & -0.16 & 0.29 & 12.8 \\
\hline Total & -0.15 & -0.15 & $0.66^{*}$ & - \\
\hline
\end{tabular}

* - significant at $\alpha=0.05$

important amino acid shaping the nutritional value of the grain (Table 6). The second limiting amino acid was Trp. However, according to Stankiewicz (2005), the most important amino acid limiting the biological value of triticale protein is Lys, followed by Val. Other studies have confirmed the role of Lys, but they also indicated the importance of Ile and Met (Brzozowska, Brzozowski, \& Hruszka, 2009).

The value of essential amino acid index (EAAI) determined against the hen egg standard was $60.4 \%$ (Table 7). For wheat, the EAAI is $63 \%$, for rye $59 \%$, while for oats $57 \%$ (Biel \& Maciorowski, 2012). In our study, weather conditions significantly differentiated the value of the integrated EAAI. In 2011, which saw heavy rains in the $\mathrm{BBCH} 73 \mathrm{BBCH} 89$ stage (Table 2), the EAAI was higher in comparison with the year 2014. Similarly, Zhang et al. (2017), based on their studies with winter wheat, indicated that under rainfed conditions improving essential amino acid index can be achived.

In our studies, under $50 \%$ of cereals in the crop rotation, the EAAI was higher than under cereal monoculture (a $100 \%$ of cereals in crop rotation). Growing triticale under the intensive technology

Chemical score (CS) of restrictive amino acid(s) (\%)

Table 6

\begin{tabular}{|c|c|c|c|c|c|c|c|c|c|c|}
\hline $\begin{array}{c}\text { Amino } \\
\text { acid }\end{array}$ & Thr & Val & Ile & Leu & Phe + Tyr & His & Lys & Arg & Met + Cys & Trp \\
\hline CS & 78 & 75 & 71 & 86 & 84 & 123 & 53 & 76 & 75 & 64 \\
\hline
\end{tabular}




\section{Essential amino acid index (EAAI) of winter triticale grains depending on the year of harvest, production technology, and a cultivar $(\%)$}

\begin{tabular}{|c|c|c|c|c|c|c|c|c|c|}
\hline \multicolumn{2}{|c|}{ The year of harvest } & \multicolumn{3}{|c|}{$\begin{array}{l}\text { Percentage of cereals in the crop } \\
\text { rotation, } \%\end{array}$} & \multicolumn{2}{|c|}{ Production technology } & \multicolumn{2}{|c|}{ Cultivar } & \multirow[t]{2}{*}{ Mean } \\
\hline 2011 & 2014 & 50 & 75 & 100 & integrated & intensive & Pizarro & Pigmej & \\
\hline $62.7 \mathrm{a}$ & $58.4 \mathrm{~b}$ & $62.0 \mathrm{a}$ & $60.8 \mathrm{ab}$ & $58.6 \mathrm{~b}$ & $59.3 b$ & $61.7 \mathrm{a}$ & $61.6 \mathrm{a}$ & $59.4 \mathrm{~b}$ & 60.4 \\
\hline
\end{tabular}

$\mathrm{a}, \mathrm{b}$ - different letters denote statistically significant differences $(\alpha=0.05)$.

increased the EAAI compared to the integrated technology. The value of this index was higher for cultivar 'Pizarro' than for 'Pigmej'.

\section{Conclusions}

The content of amino acids in winter triticale is a strongly genetically-determined trait, however, it also depends on the production technology (the amount of fertilizers and pesticides used), the percentage of cereals in the crop rotation and on weather conditions (precipitation and temperature).

The contents of essential and non-essential amino acids in triticale grains and the nutritive value of the protein (EAAI) are higher under intensive technology (where high doses of NPK and pesticides are used), and with $50 \%$ of cereal grains in the crop rotation as compared to $75 \%$ and $100 \%$, and in the traditional cultivar 'Pizarro' as compared to the dwarf one 'Pigmej'. Abundant rainfall during the $\mathrm{BBCH}$ 73- $\mathrm{BBCH} 89$ stage causes the increase in the content almost all essential and non-essential amino acids (except Val, Pro and Gly). The greatest influence of weather conditions on the content of amino acids in triticale grains was noted in Tyr. The main amino acid which limited the quality of protein in the triticale grains is lysine. This amino acid showed a high variability in years and cultivars but weak response to the agrotechnical factors (production technology and the percentage of cereals in the crop rotation).

\section{References}

1. Alijošius, S., Švirmickas, G.J., Bliznikas, S., Gružauskas, R., Šašytė, V., Racevičiūtė-Stupelienė, A., Kliševičiūtè, V., \& Daukšien, A. (2016). Grain chemical composition of different varieties of winter cereals. Zemdirbyste-Agriculture, 103, 273-280.

2. Biel, W., \& Jacyno, E. (2013). Chemical composition and nutritive value of spring hulled barley varieties. Bulgarian Journal of Agricultural Science, 19, 721-727.

3. Biel, W., \& Maciorowski, R. (2012). Assessing nutritional value of grains of selected wheat cultivars. Food Science Technology Quality, 2, 45-55.

4. Brzozowska, I., Brzozowski, J., \& Hruszka, M. (2009). Effect of various methods of weed control and nitrogen fertilisation on biological value of winter triticale grain protein. Fragmenta Agronomica, 26, 16-25. (in Poland)

5. Coffey, M.T., \& Gerrits, W.J. (2009). Digestibility and feeding value of B858 triticale for swine. Journal of Animal Science, 66, 2728-2735.

6. Djekić, V., Milovanović, M., Popović, V., Milivojević, J., Staletić, M., Miodrag, J., \& Perišić, V. (2014). Effects of fertilization on yield and grain quality in winter triticale. Romanian Agricultural Research, 31, 175-783.

7. FAO/WHO (Food \& Agriculture Organization /World Health Organization). (1985). Energy and protein requirements. Technical Report Series. 522. Roma. Retrieved February 17, 2016, from: http://fao.org/ docrep/003/aa040e/aa040e00.htm.

8. FAOSTAT (2016). FAO Statistics Division. Retrieved March 3, 2016, from: http://faostat.fao.org.

9. Fernandez-Figares, I., Royo, C., Ramos, J.M., Garcia, Del., \& Moral, F.L. (2000). Amino-acid composition and protein and carbohydrate accumulation in the grain of triticale grown under terminal water stress simulated by a senescing agent. Journal of Cereal Science, 32, 249-258.

10. Gałązka, A., Gawryjołek, K., Grządziel, J., \& Księżak, J. (2017). Effect of different agricultural management practices on soil biological parameters including glomalin fraction. Plant Soil Environment, 63. DOI: 10.17221/207/2017-PSE.

11. Järvan, M., Lukme, L., Adamson, A., \& Akk, A. (2017). Responses of wheat yield, quality and breadmaking properties on the sulphur fertilization. Acta Agriculturae Scandivanica, 6, 444-452.

12. Jaśkiewicz, B., \& Szczepanek, M. (2016). Crop management and variety have influence on alkylresolcinol content in triticale grain. Acta Agriculturae Scandivanica, 66, 570-574. 
13. Lista opisowa odmian (Variety Descriptive List) (2017). (Research Centre for Cultivar Testing) (COBORU), Słupia Wielka, 108-119. (in Polish).

14. Marczak, B., Stankiewicz, C., Starczewski, J., Steć, E., \& Mitrus, J. (2001). The influence of growth retardants and nitrogen fertilization on chemical composition of winter triticale grain. Rostlinna Vyroba, 47, 371-374.

15. Shewry, P.R. (2007). Improving the protein content and composition of cereal grain. Journal of Cereal Science, 46, 239-250.

16. Spychaj-Fabisiak, E., Barczak, B., Nowak, K., \& Jagielski, J. (2014). Amino acid composition of winter wheat grain protein depending on the seed certification class and on the cultivar. Romanian Agricultural Research, 31, 89-94.

17. Stankiewicz, Cz. (2005). Skład aminokwasowy i wartość biologiczna białka pszenżyta jarego w zależności od gęstości wysiewu i stosowanych herbicydów (Effect of the sowing density and herbicydes on the composition of amino acids and biological value of spring triticale protein). Acta Scientarum Polonorum, Agricultura, 4(1), 127-139. (in Polish).

18. Zhang, P., Ma, G., Wang, C., Lu, H., Li, S., Xie, Y., Ma, D., \& Zhu, Y. (2017). Effect of irrigation and nitrogen application on grain amino acid composition and protein quality in winter wheat. PLoS ONE 12(6), e0178494. DOI: 10.1371/journal.pone.0178494. 